\title{
Experiential Learning: Exploring Human Literacy of English Language Teaching in Education 4.0
}

\author{
Susanti Malasari ${ }^{1}$, Lemmuela Alvita Kurniawati ${ }^{2}$ \\ \{ susantimalasari@untidar.ac.id ${ }^{1}$, pipitkh@staff.ukdw.ac.id ${ }^{2}$ \} \\ ${ }^{1}$ Universitas Tidar, Indonesia \\ ${ }^{2}$ Universitas Kristen Duta Wacana, Indonesia
}

\begin{abstract}
Experiential learning, which provides rooms for students to explore, create a project, interact with their environment, real situation, simulation, and guided discovery, has become the focus of Education 4.0. The nature of it, which offers students ways to experience and apply what they have learned in class through social interactions, real-world tasks, and interpersonal experience is manifested in the development of students' human literacy. This study explores the perceptions of English teachers towards the impact of experiential learning in exercising students' human literacy to be better prepared in facing industrial revolution 4.0. This study is qualitative in nature and employs a questionnaire and interview to gather the data. Eight teachers from a private school that offers the International Primary Curriculum (IPC) participated in this study. The results of the study reveal that the majority of the English teachers have positive perceptions towards experiential learning. As an embodiment of human literacy, it helps students connect what they have learned with the realworld experience, promote collaboration, critical thinking, problem-solving, and communication skills, and use technology effectively. Pedagogical and practical implications of experiential learning embody the development of human literacy in English language teaching in Education 4.0 were discussed in the study.
\end{abstract}

Keywords: experiential learning, human literacy, Education 4.0, English language teaching

\section{INTRODUCTION}

Learning English is not something new in Indonesian education. Almost all schools in Indonesia have English subject in their curriculum. Even though English becomes a supplementary subject in elementary school since the 2013 curriculum is applied, it does not influence the condition of English education in primary school. They always develop ways to improve English education at the primary level by conducting English class as an extracurricular activity at school or making it a compulsory local content subject. Typically, English language teaching in elementary school is done based on the school's needs. Most schools have their English language teaching conducted traditionally. The students are asked to sit and listen to their teacher's explanation and do some tasks given by the teacher.

In this more modern school, many teachers have developed more interactive ways in their teaching and learning processes. Experiential learning is one of the ways of teaching English 
that is developed by some teachers, especially in some schools that offer International Primary Curriculum (IPC). Experiential learning means learning from experience or learning by doing. Experiential education first immerses learners in an experience and then encourages reflection about the experience to develop new skills, new attitudes, or new ways of thinking[1]. The experiential learning is believed as one of nine trends related to Education 4.0 proposed by Hussin [2]. Students will be exposed to more hands-on learning through field experiences such as internships, mentoring projects, and collaborative projects [3].

In education 4.0, there are three new literacies needed. Three new literacies, which prepare students to compete in a labor market in which smart machines work alongside humans are data literacy, technological literacy, and human literacy[4]. Human literacy - the humanities, communication, and design - should be owned by students to function as a human being [4]. Human literacy is the ability to be creative, solve problems, and communicate and collaborate with others. Those abilities are important to make the students function well in their societies. Human literacy is important to survive in this era, and the goal is that students can function well in their environments and societies [4].

In the context of English as a Foreign Language (EFL), there has been a growing number of studies on experiential learning. An experimental study to investigate the effectiveness of experiential learning in listening comprehension lessons in an EFL context was conducted by using class story language experience [5]. The results of the study showed significant improvement in students' listening scores. Meanwhile, in the Indonesian context, a study was conducted on integrating innovative experiential learning in cyclic teaching sessions of English-speaking classes[6]. The findings of the study indicated that the implementation of experiential learning improved the students' speaking skills. Although many studies have been discussing experiential learning in EFL context, a few of which examine experiential learning in relation to human literacy and education 4.0. In other words, this area of research is underdeveloped compared to other experiential learning studies. Consequently, this study is aimed to explore the perceptions of English teachers towards the impact of experiential learning in exercising students' human literacy to be better prepared in facing industrial revolution 4.0.

Experiential education first immerses learners in an experience and then encourages reflection about the experience to develop new skills, new attitudes, or new ways of thinking [1]. The experiential learning enables students to directly involve in the learning process in order to get learning experience which can ease the process of acquiring knowledge. In experiential learning, students also get some life skills such as communication and problem solving because the students are trained to cooperate with others during the learning process.

There are six criteria proposed by Kolb [1]. First, "learning is best conceived as a process, not in terms of outcomes." The process of learning is very important to improve the quality of learning. The more teachers engage students in the process of learning, the higher chance the students get to enhance their learning. In experiential learning, students are involved in the learning process, and they are required to be active because every learning process is meaningful for students. In the learning process, students can explore, research, and find out things they are learning. This process is believed to be the golden moment of learning, a moment where students can acquire the knowledge well. Second, "all learning is relearning." Since the experiential learning is conceived as a process, the learning conducted in experiential learning is repeated and relearned. It means that students can learn one thing and relate it to their real world. Third, "learning requires the resolution of conflicts between dialectically opposed modes of adaptation to the world." In experiential learning, students are engaged in the learning processes by having discussions and collaborations. Those learning 
processes train students to solve problems when they face different ideas and beliefs. Fourth, "learning a holistic process of adaptation." In experiential learning, students are expected to cooperate and collaborate in either small and large class discussions or class activities. In this process of learning, students' soft skills, such as leadership, communication, problem-solving, decision making, and creativity are indirectly developed. In fact, those skills are mostly needed by students to be fully developed human. Fifth, "learning results from synergic transactions between the person and the environment." In experiential learning, students are encouraged to relate their learning with the real environment. This kind of process enables students to have good bound with the environment. The closer the students with the environment, the greater experience they have. It can help them function well in the environment. At last, "learning is the process of creating knowledge." Experiential learning students learn both academically and socially. Academically, students acquire knowledge that they need to develop their personal knowledge and understanding of a certain subject. Meanwhile, socially, sharpen their soft skills, which are developed by the learning process of acquiring knowledge.

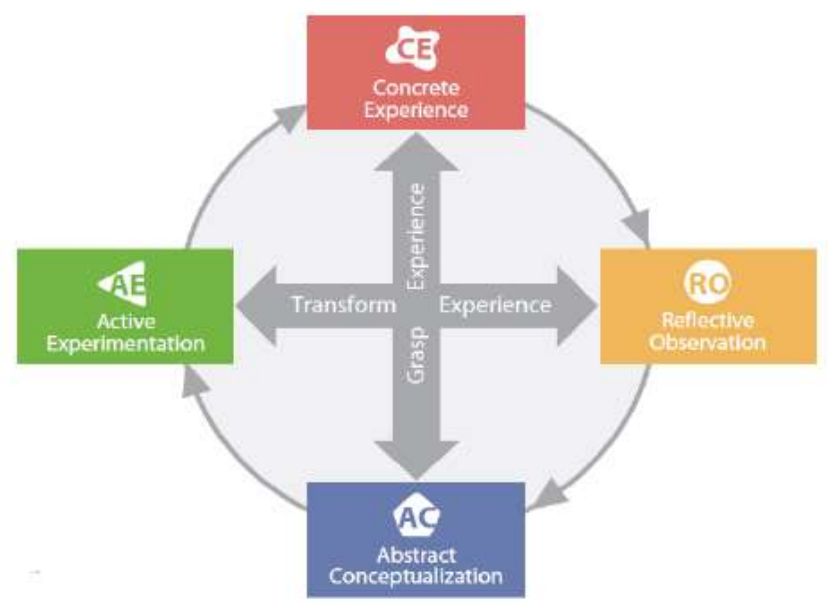

Figure 1. The cycle of experiential learning

Experiential learning is best described as the process of acquiring knowledge through the transformation of experience. Knowledge is the combination of grasping and transforming experience [1]. The figure above shows that experiential learning students can have ideal learning because experiential learning lets students learn from concrete experience and guide students in creating new experiences.

Meanwhile, Aoun [3] proposed three new literacies needed to face the Industrial Revolution 4.0 are data literacy, technological literacy, and human literacy. Data literacy is the ability to read, analyze, and utilize information in the digital world. Technological literacy is the ability to understand how the machine works, technological applications, and engineering principles. In addition, human literacy is the ability to communicate and collaborate with others. Communicative skill is the key component of modern education; it is needed to interact with different kinds of people in society. Human literacy is important to be developed in education 4.0 because it enhances students' leadership and community building, 
which plays an important role for them to function well in society. Collaboration is "a situation in which two or more people learn or attempt to learn something together" [3]. Meanwhile, collaboration trains the students to be independent learners; it teaches the students to share knowledge with other students. It also trains students to become emotionally-mature by managing students how to work in a team as well as how to respect others. Collaboration skill is essential for students' human literacy development since it highlights the importance of cooperating and working with others.

Hussin proposed nine trends related to Education 4.0 [2]. First, "learning can be taken place anytime, anywhere." In Education 4.0., the availability of the internet makes e-learning and flipped learning very common. Distance learning becomes an alternative when classroom learning is not available. Besides, flipped learning also becomes an alternative to create more interactive learning for students. In addition, the traditional learning which is conducted in the classroom is modified as outdoor learning where the students can explore and research more on what they are learning. Second, "learning will be personalized to individual students." Students are always encouraged to do their best. Once the students have mastered a certain material, they will be encouraged to finish another task. Students are always encouraged with a positive learning experience to develop their confidence in learning. Third, "students have a choice in determining how they want to learn." In Education 4.0, students are free to choose methods, techniques, and tools they want to use.

Fourth, "students will be exposed to more project-based learning." The project-based learning trains students to do a project at a certain time. This project-based learning enables students to work collaboratively with other students, learn how to respect others as well as how to manage the time. Fifth, "students will be exposed to more hands-on learning through field experiences such as internship, mentoring projects, and collaborative projects." Hands-on learning enables students to learn from their environment, and the activities are designed to make the students more engaged in the teaching and learning process. Sixth, "students will be exposed to data interpretation in which they are required to apply their theoretical knowledge to numbers and use their reasoning skills to make inferences based on logic and trends from given sets of data." In education 4.0, the data will be mostly processed using computers instead of being processed manually.

Seventh, "students will be assessed differently, and the conventional platforms to assess students may become irrelevant or insufficient". Students are assessed by two kinds of activities throughout the teaching and learning process. The assessment of factual knowledge is done in the teaching and learning process. Meanwhile, the assessment of the application of knowledge is done when the students are working with their projects. Eighth, "students' opinions will be considered in designing and updating the curriculum." In education 4.0, schools are more open to students' ideas. Students' opinions are very useful for the curriculum developer in updating the curriculum, which is appropriate for the students' needs. At last, "students will become more independent in their own learning, thus forcing teachers to assume a new role as facilitators who will guide the students through their learning process." Education 4.0 is the implication for student-centered learning; therefore, students are expected to be more independent; they explore, research, and find out about what they are learning by themselves. In this more modern education, teachers only need to guide students in their learning process, they are not the center of learning anymore. 


\section{RESEARCH METHOD}

This study is aimed to uncover the English teachers' perceptions towards the impact of experiential learning in exercising students' human literacy to be better prepared in facing industrial revolution 4.0. Qualitative data analysis was employed in this study in order to provide rich and comprehensive data and to attain the objective of this study. Questionnaire and interviews were employed to explore how teachers perceive experiential learning in practicing students' human literacy to prepare students in the industrial revolution 4.0 era.

Conducted in a bilingual private school, Yogyakarta municipality, Indonesia, the research setting offers International Primary Curriculum (IPC). It requires the teachers to use English as a medium of instruction (EMI) in delivering the Cambridge International Primary Programme (CIPP) class consisting of English, Math, and Science subjects and IPC topics. Interestingly, teachers in this school implement an experiential learning approach in CIPP and IPC subjects to facilitate students learning. They direct students to apply their knowledge they get from the classroom to real-world situations by using various class activities, such as experiments, art projects, role-plays, problem-solving, case studies, and/or simulations. As this study aims to explore English teachers' perceptions towards the impact of experiential learning in exercising students' human literacy, 8 (eight) English teachers of the bilingual private school were involved voluntarily in this study. The participants provided rich and comprehensive data about how they perceived the implementation of experiential learning in their English class in exercising human literacy through collaboration, communication, problem-solving, and creative thinking skills. The selection of both the research setting and the participants, therefore, evidently could unveil the complexity and richness of data being studied.

Questionnaire and interview were used as the data gathering instruments to investigate the English teachers' perception towards the implementation of experiential learning in exercising students' human literacy to prepare them facing industrial revolution 4.0. The questionnaire was designed by using Google Form and distributed to the participants by using the WhatsApp mobile application. The questionnaire consists of 9 (nine) statements with a 4point Likert scale ranging from "Strongly disagree" (1) to "Strongly Agree" (4) and 4 (four) open-ended questions. Participants were given 4 (four) days to fill out the questionnaire. Additionally, supplementary data was gathered from the interview to ask for clarification, to confirm understanding, and to get elaboration of participants' responses in open-ended questionnaire questions. Upon completion, we analyzed the participants' responses from both the questionnaire results and the interview verbatim.

The data gathered from the questionnaire were statistically computed by Google Form to find out the percentage of each statement response, then each response was analyzed descriptively. In addition, the data from the interview were transcribed, analyzed, coded, and described to reveal the English teachers' perception towards the implementation of experiential learning in exercising students' human literacy to prepare them facing industrial revolution 4.0 .

\section{FINDINGS AND DISCUSSION}

This section presents and discusses the perceptions of English teachers towards the impact of experiential learning in exercising students' human literacy to be better prepared in facing industrial revolution 4.0. The discussion is presented based on the findings gathered from the questionnaire and the interview. 
The findings from the questionnaire related to English teachers' perceptions towards the impact of experiential learning in exercising students' human literacy to be better prepared in facing industrial revolution 4.0 is presented in table 1 below.

Table 1. English teachers' perceptions toward the impact of experiential learning

\begin{tabular}{|c|c|c|c|c|c|}
\hline No & Statements & $\begin{array}{l}\text { Strongly } \\
\text { Disagree }\end{array}$ & Disagree & Agree & $\begin{array}{c}\text { Strongly } \\
\text { Agree }\end{array}$ \\
\hline 1 & $\begin{array}{l}\text { Experiential learning, learning by } \\
\text { exploring and doing, develops students' } \\
\text { creativity, collaborative work, } \\
\text { communication skills, problem-solving, } \\
\text { and critical thinking. }\end{array}$ & - & - & $37.5 \%$ & $62.5 \%$ \\
\hline 2 & $\begin{array}{l}\text { I encourage myself to apply experiential } \\
\text { learning in my English class. }\end{array}$ & - & - & $50 \%$ & $50 \%$ \\
\hline 3 & $\begin{array}{l}\text { Students are more engaged in working } \\
\text { collaboratively when I conduct } \\
\text { experiential learning in my English class. }\end{array}$ & - & - & $50 \%$ & $50 \%$ \\
\hline 4 & $\begin{array}{l}\text { In implementing experiential learning, I } \\
\text { require myself to use technology } \\
\text { optimally in teaching to make students } \\
\text { better prepared in facing Education } 4.0 \text {. }\end{array}$ & - & $12.5 \%$ & $37.5 \%$ & $50 \%$ \\
\hline 5 & $\begin{array}{l}\text { Experiential learning facilitates students to } \\
\text { use technology effectively in their } \\
\text { learning process. }\end{array}$ & - & - & $50 \%$ & $50 \%$ \\
\hline 6 & $\begin{array}{l}\text { English teachers develop students' human } \\
\text { literacy by applying experiential learning } \\
\text { in teaching and learning activities. }\end{array}$ & - & - & $62.5 \%$ & $37.5 \%$ \\
\hline 7 & $\begin{array}{l}\text { Human literacy needs to be developed in } \\
\text { order to make students function well in } \\
\text { their society. }\end{array}$ & - & $12.5 \%$ & $37.5 \%$ & $50 \%$ \\
\hline 8 & $\begin{array}{l}\text { Experiential learning demonstrates } \\
\text { students' leadership and community } \\
\text { building. }\end{array}$ & - & - & $75 \%$ & $25 \%$ \\
\hline 9 & $\begin{array}{l}\text { Experiential learning and human literacy } \\
\text { help students face education } 4.0 \text {. }\end{array}$ & - & - & $37.5 \%$ & $62.5 \%$ \\
\hline
\end{tabular}

The table above indicates that the participants had positive perceptions towards the impact of experiential learning in exercising students' human literacy to be better prepared in facing industrial revolution 4.0. In statement 1 , the participants agreed (agree $=37.5 \%$, strongly 
agree $=62.5 \%$ ) that experiential learning develops students' creativity, collaborative work, communication skills, problem-solving, and critical thinking. Aligns with this, they agreed (agree $=50 \%$, strongly agree $=50 \%$ ) that they encourage themselves to apply experiential learning in their English class. The participants also agreed (agree $=50 \%$, strongly agree $=$ $50 \%$ ) that the implementation of this approach-initiated students engagement during collaborative work in class. These findings align with Kolb's six principles of experiential learning [2]. In the fourth principle, he asserts that by implementing experiential learning, teachers provide students with greater opportunities to engage in their learning process through some activities, such as collaborative work, project-based learning, problem-solving, case studies, and role-plays. These activities, therefore, help students to be fully developed humans who are able to function well in the community. Apart from that, students would develop their soft skills, i.e. leadership, decision making, communication, and problemsolving skills, which will absolutely be useful to prepare them in Education 4.0.

In relation to the integration of technological tools in English class, the participants were mostly in agreement (agree $=37.5 \%$, strongly agree $=50 \%$ ) that they used technological tools to facilitate the implementation of experiential learning in their English class. They agreed (agree $=50 \%$, strongly agree $=50 \%$ ) that the integration of technology would help students to be better prepared in Education 4.0 that requires them to be digitally literate and to use technology wisely and effectively in order to achieve learning autonomy. These findings support Fisk's nine trends of Education 4.0 (2017), affirming that in Education 4.0, students will be autonomous learners who take more responsibilities and ownership of their own learning.

In the context of human literacy, the participants were all in agreement (agree $=62.5 \%$, strongly agree $=37.5 \%$ ) that the implementation of the experiential learning approach during teaching and learning activities had a positive impact on the development of students' human literacy. Furthermore, $87.5 \%$ of the participants endorsed statement 7 , affirming that human literacy plays a significant role to help students function well in their society. Apart from students' role in the society and community, when asked if they agreed that experiential learning demonstrates students' leadership and community building, all of the participants agreed (agree $=75 \%$, strongly agree $=25 \%$ ). These findings, therefore, align with Aoun's viewpoint that human literacy as one of the three literacies in IR 4.0 is needed for the students to be able to collaborate and communicate well in the society and community.

With respect to experiential learning, human literacy, and Education 4.0, the participants agreed (agree $=37.5 \%$, strongly agree $=62.5 \%$ ) that experiential learning and human literacy help students face education 4.0. Experiential learning, learning through experiences, gives opportunities for students to engage fully in their learning experiences through various activities. They have the freedom to decide their actions and plans during the learning process. This learning approach provides students with some collaborative work, discussion, and other related activities done collaboratively [1]. These activities help students develop their human literacy, which is needed in Education 4.0.

The interview results are used as the supplementary data in order to strengthen the participants' perception of implementing experiential learning in English class. From the interview results, it can be seen that the implementation of experiential learning in English class has positive impacts on developing students' human literacy, especially in shaping students' leadership and community building. In this case, the participants developed students' leadership and community building by assigning students to do group discussions.

"In order to develop students' leadership and community building, we usually ask the students to work in groups. In the group discussion, we can see some students 
who are dominant or always want to be the leader of the group. Therefore, we can see whether the students can guide or help their friends in a group discussion. We can also see whether they can solve problems by asking for and giving suggestions as well as cooperate actively in the group discussion. By giving that kind of activity, we can see their leadership and how they build their community." (SP5, KS/2019)

Kolb states that learning requires the resolution of conflicts between dialectically opposed modes of adaptation [1]. By working in groups, students learn to communicate with their peers as well as develop their problem-solving skills. Furthermore, group discussion helps students to improve their leadership and collaborative skills. The ability to communicate and collaborate with others is one of the human literacy skills that are useful for students to function well in their society [3].

Considering the advantages of human literacy for the students, the participants monitored the students' human literacy development in implementing experiential learning, which was done by observing the students' behavior both in and outside the class.

"In order to know the development of human literacy by seeing how they implement the materials they have learned in class in their real life. We usually observe them both in or outside the classroom to see whether they have implemented what they have learned in their daily life for example, how they express their feelings and ideas in English. We also give them some reflection questions whether they have understood the materials they learned especially the materials which are related to other cultures that are different from Indonesian culture. During my observation, I always pay attention to how the students use English to present their ideas. By doing that, I know whether the students have used English correctly or not as well as the manner of using the language whether they are polite or impolite. I also give the students some tests to measure the students' ability to think critically when they are in the same situation as what they have learned in the class."

(SP1, KS/2019)

Learning is a holistic process of adaptation which means that the outcomes of learning should shape students as the students as the total person will function well in their environment [7]. From the interview results it can be seen that the experiential learning implemented in participants' school also consider the importance of their students' human literacy development.

Experiential learning enables students to experience all the process of learning; experiencing, reflecting, thinking and acting [1]. During the process of learning, students also learn how to shape their human literacy; collaboration, communication, creativity and critical thinking, the skills that are needed in education 4.0. It means that by implementing experiential learning students can be better prepared to face education 4.0.

"Experiential learning is a kind of learning that is designed in order to make students learn from the experience. In experiential learning students learn by doing, researching and experiencing; Therefore, it is hoped that if in the future students are faced with some problems in their daily life, they will be able to overcome those problems well because they have experienced such problems when they are learning in the class. This case will be different if students only learn theoretical things, students will have difficulties in solving problems in the future. In addition, experiential learning prepares the students with some aspects 
that students have to master in order to face education 4.0. Therefore, we always try to give materials that cover all aspects that must be learned in education 4.0." (SP7, KS/2019)

Human literacy is the ability to communicate and collaborate with others, solve problems, and to be creative [3]. In experiential learning, students are trained to connect their learning experience with real life. In this case, it can be seen that human literacy and experiential learning has interconnectivity that can help students face education 4.0.

The core idea of education 4.0 is the collaboration between humans and machines where humans can do their work by managing the digital system and controlling automatic machines by using the internet. It reveals that using technology eases teachers in conducting the teaching and learning process.

"Usually I use PowerPoint slides to show the materials, pictures or exercises that have been modified as games. I also show videos that are related to the materials discussed in the class as well as use google search and YouTube. This year, we get our English book along with the $\mathrm{CD}$ so that we can play the recording to the students in order to get the students used to listen to native speakers' pronunciation."

From the interview results above, it can be seen that the participants made use of technology in implementing experiential learning in their English class. Besides, the participants also encouraged their students to use technology in their learning process as well as manage their students to use technology effectively.

"At school, students still have limited access on the technology because most of the technological facilities are used for the teachers; students are allowed to use the facilities with the teachers' guidance. For example, if teachers ask the students to present their work to the class, usually teachers get the materials ready for them. In other words, the use of technology for students at school is still at the minimum level. We also rarely ask the students to do their assignment using the internet because they always tell the teachers that they are not allowed to access the internet even though the teacher has insisted them that parents will allow them to give them access if it is for educational purposes."

(SP3, KS/2019)

It can be inferred that the use of technology in the participant's school is still limited for the students. However, it does not mean that students are restricted to use the internet; students are allowed to access the internet with the teachers' guidance. It can be concluded that teachers always encourage students to use the internet as effective as possible.

Considering the benefits of implementing experiential learning, all participants were motivated to implement experiential learning in their English class. Therefore, they encountered some challenges in implementing the approach.

"In order to overcome the challenges, we need to find some solutions. Here, I divide the solutions into two; preventive and solution to the occurred problems. To prevent the problems, I usually find some references related to the teaching and learning process or I try to remember the experiences of how to solve problems that I have ever faced or some problems that need more attention. We also do some preventive solutions to prevent the condition of the chaotic class caused by our students' daily mood changes. Besides, we often have sharing sessions on how other teachers solve their problems in implementing experiential 
learning in their English class; so, if we have similar problems, we know how to solve those problems."

(SP8, KS/2019)

\section{IMPLICATION AND CONCLUSION}

From the discussion above it can be concluded that the participants have positive perception towards the implementation of experiential learning to sharpen students' human literacy to better prepare them facing Education 4.0. The participants agreed that experiential learning has successfully developed students' human literacy skills which can help them to function well in their society. Furthermore, it was revealed that experiential learning helped students develop creativity, collaborative work, communication skills, problem solving, and critical thinking. Those attributes as the embodiments of human literacy were considered useful for students in their learning process in the evolution of Education 4.0. Accordingly, based on the findings, EFL teachers are encouraged to implement experiential learning in their class to provide opportunities for students to have ownership of learning, practice their human literacy, and be more prepared in facing IR 4.0. Further studies can replicate this study with different settings and more participants and focus on EFL students' perceptions in experiencing experiential learning.

\section{References}

[1] A. Y. Kolb and D. A. Kolb, "Experiential learning theory: A dynamic, holistic approach to management learning, education and development," SAGE Handb. Manag. Learn. Educ. Dev., no. May 2015, pp. 42-68, 2009, doi: 10.4135/9780857021038.n3.

[2] A. A. Hussin, "Education 4.0 Made Simple: Ideas For Teaching," Int. J. Educ. Lit. Stud., vol. 6, no. 3, pp. 92-98, 2018.

[3] N. Yelland et al., "State of the Art and Future Trends on Learning," Procedia - Soc. Behav. Sci., vol. 232, no. April, pp. 288-304, 2015, doi: 10.1016/j.sbspro.2016.10.085.

[4] Afrianto, "Being a Professional Teacher in the Era of Industrial Revolution 4.0: Opportunities, Challenges and Strategies for Innovative Classroom Practices Afrianto Faculty of Teachers Training and Education (FKIP), Universita," English Lang. Teach. Res., vol. 2, no. 1, pp. 1-13, 2018.

[5] I. Tahir, "The Effect of Implementing the Experiential Learning Model in Listening Comprehension for the Eleventh Graders at SMAN 1 Telaga Biru," Adv. Lang. Lit. Stud., vol. 8, no. 5, p. 46, 2017, doi: 10.7575/aiac.alls.v.8n.5p.46.

[6] J. Sosial, I. Bagus, N. Mantra, I. N. Astawa, I. Ayu, and M. Sri, "Integrating Innovative Experiential Learning in Cyclic Teaching Sessions of English Speaking Classes," vol. 8, no. 2, pp. 185-190, 2018.

[7] L. Angelianawati, "Being an Englishteacher in Industrial Revolution 4.0: an Overview About Roles, Challenges, and Implications," J. Din. Pendidik., vol. 11, no. 3, p. 307, 2019, doi: 10.33541/jdp.v11i3.896. 
